\title{
Literarisierung Reconsidered in the Context of Sultanic Biography: The Case of Shāfi b. 'Alī's Sīrat al-Nāṣir Muḥammad (BnF Ms Arabe 1705)
}

\author{
Gowaart Van Den Bossche
}

While the historiography of late medieval Egypt and Syria is exceptionally well documented and many, if not most, of its major sources have by now been edited and studied, manuscript repositories still contain several historical texts that have received little to no attention from scholars. This essay will present one such unpublished and mostly unstudied excerpt of a historical biography devoted to Sultan al-Nāșir Muhammad (r. 693-4/1293-4, 698-708/1299-13o9, 709-41/1309-41) preserved in the manuscript Arabe 1705, held by the Bibliothèque Nationale de France in Paris. It will be argued that its author can be identified as Shāfi' b. 'Alī (d. 73o/133o), who also wrote two well-known historical biographies of the sultans Baybars (r. 658-76/126o-77) and Qalāwūn (r. 678-89/1281-9o). Using this particular text as a case study, I will discuss how the concept of "Literarisierung," first applied to Mamluk historiography by Ulrich Haarmann almost half a century ago, may still be used fruitfully to think about how historiography and literary modes of expression interacted.

In a famous article published in 1971, Ulrich Haarmann argued that historiography in late medieval Egypt and Syria underwent a particular innovation, which he defined as a "Literarisierung der inneren Form," or "literarization of the inner form." According to Haarmann, the chronicles and biographical dictionaries produced between the 7 th/13th and early 1oth/16th centuries should not be considered as innovative in their formal, outer form, as they generally adhered to characteristics set by earlier precedents. There was, however, something distinctive about their inner form (i.e., on the level of individual segments within the larger works). At this level, one would come across a much higher attestation of literary elements, that is, anecdotes, topoi, colloquialisms, and especially miraculous stories, 'ajā'ib wa-gharā'ib pervading the annalistic historical narratives. ${ }^{1}$ This argument and related observations from Haarmann's dissertation, Quellenstudien zur frühen Mamlukenzeit, sparked a

1 Haarmann, Auflösung 48-50. 
debate in German academia about the supposed distinction between the historical as a science ( $\mathrm{ilm}$, a term more accurately rendered as a field of knowledge) and the literary as equivalent to entertaining digression. This point was taken up somewhat more stringently by Barbara Langner in her dissertation on popular culture in this period, where she argued that this historiographical tendency was the result of a growing popularization of historiography. She also translated a number of examples of the phenomenon. ${ }^{2}$ Haarmann's and Langner's main challenger was Ernst Radtke, who argued that contemporary authors did not make a distinction between the historical as science rather than as literary and that the elements noted by Haarmann and Langner did not constitute a new development. ${ }^{3}$ Despite Radtke's criticisms, the idea of "Literarisierung" has been implicitly and often rather uncritically accepted by many later researchers. ${ }^{4}$ Although in Haarmann's and Langner's definition the idea denoted such anecdotal elements, the use of the term "Literarisierung" in the context of historiography does create some confusion: Should it mean, in keeping with Haarmann's observations, that literary elements appear in historiography or rather that history is written according to a literary logic?

Haarmann's argument was about content, and he implicitly suggested that simply being aware of literarization made it possible to distinguish between the facts and the fanciful, so to speak. This essentially positivistic idea may also be found in the influential study of early Islamic historical narrative written by Haarmann's contemporary Albrecht Noth. ${ }^{5}$ The stories and anecdotes may, of course, also be a worthwhile subject of research in themselves, but essentially, these should be studied as literary subject matter and not taken at face value. In addition to Radtke's objections against Haarmann's evaluation of Mamluk distinctiveness, we can formulate the remark that this is a very reductive interpretation of what literature and literary forms of expression amount to. In fact, if we look at the history of the term "Literarisierung" in German research, it becomes clear that Haarmann's conceptualization was somewhat idiosyncratic. Consider, for example, the following quote by Gustav von Grunebaum from his influential study Medieval Islam, taken from a section where he evaluates a letter written in the $i n s h \vec{a}^{3}$ tradition:

2 Langner, Untersuchungen 127-85.

3 Radtke's earliest engagement with the issue may be found in the introduction (Einleitung) to his edition of the first volume of Ibn al-Dawādārīs Kanz al-durar wa-jāmi' al-ghurar. He returned to the topic several times: Radtke, Literarisierten; Weltgeschichte 186-95. He changed his mind slightly in Radtke, Literarisierung.

4 Holt, Early 35-6; Guo, Early 87-96; Weintritt, Formen; Robinson, Islamic 10o; Conerman, Tankiz 4; Mazor, Topos 105-6.

5 Noth, Quellenkritische. Later translated and updated in Noth and Conrad, Early. 
Abū l-'Alā' [al-Ma'arrī]'s letter is an extreme but by no means isolated example of that dissolution of thought and sentiment into musical phrase, that sacrifice of sense to sound, which so deeply affected the literatures of the Muslim peoples. The trend begins in the 8th century, to win an uncontested victory during and after the 11th century. Literarization of ideas and rhetorization of style - there is no Arabic or Persian after A.D.10oo who does not, in some measure, exhibit their trace. Presentation and content interact. The supremacy in prose and poetry of the writer-virtuoso goes far to inject into any concept of human perfection an element of the versatile, widely read, quick-witted, and entertaining littérateur. ${ }^{6}$

The quote is, of course, problematic in its negative attitude toward literarization, but von Grunebaum's evaluation of the literary as a stylistic logic, as fundamentally related to a register of language, may, in fact, be useful in evaluating the ways in which historiography can be interpreted within conceptualizations of literature that circulated among late medieval authors. Perhaps most importantly, unlike Haarmann, von Grunebaum also argued that the form of presentation and its content were fundamentally intertwined and can thus not be separated in satisfactory ways. This is an important observation, which also resonates with medieval evaluations of rhetoric and linguistic construction in general. $^{7}$

One surprising result of Haarmann's conceptualization of literature as equivalent to the anecdotal is that according to him, the small corpus of sultanic biographies (sira, pl. siyar) written by chancery officials during the $7^{\text {th }} / 3^{\text {th }}$ and early 8th/14th centuries fell outside of the period's literarization because they were said to build on earlier examples and did not contain as many anecdotes. The examples are never named explicitly, but one assumes Haarmann referred to the works of Bahā' al-Dīn b. Shaddād (d. 632/1234) and 'Imād alDīn al-Iṣfahānī (d. 597/1201) on Saladin (d. 589/1193) — which are not actually that far removed in time from the early Mamluk examples-and the important but somewhat singular Kitāb al-yamīnī written by Abū Nașr al-'Utbì (d. 1040). Furthermore, in his major study Quellenstudien zurfrühen Mamlukenzeit, Haarmann evaluates the three siras written by Ibn 'Abd al-Ẓāhir as "quantitativ and qualitativ drei der bedeutesten Quellen zur frühen Mamlukenzeit," because

6 Von Grunebaum, Medieval 229-30. Italics mine.

7 For a rare early criticism against the dichotomy between content and form proposed by Haarmann and like-minded researchers, see Malti-Douglas, Dreams 139-41. 
they were widely used as source material for later historians. ${ }^{8}$ One wonders how texts that supposedly fell outside of a nascent literarized historical tradition could at the same time be highly influential on works firmly within that tradition.

This essay aims to present an as-yet-unedited text and argue by way of examples taken from that text for a different interpretation of Literarisierung that is related to von Grunebaum's evaluation but enriched by more recent frameworks from studies on medieval Arabic literature, especially by Thomas Bauer and Rebecca Gould, and with general ideas of historical emplotment as propounded by Hayden White and Paul Ricoeur. To refer directly to Hayden White, part of what I will be interested in, is the "content of the form," the meaning that is communicated by way of the narrative structure used by an author. ${ }^{9}$ It will furthermore be my contention that reading the corpus of sultanic biographies, to which this particular text belongs, as merely functioning within a logic of legitimization is too reductive. Instead, I propose a broadly defined evaluation of patronage as a performative negotiation of social position, in which agents employed their mastery of various literary registers as a distinctive form of cultural capital. ${ }^{10}$

The manuscript Arabe 1705 held by the Bibliothèque Nationale in Paris has not been studied nor identified in any detail before. ${ }^{11}$ This is somewhat remarkable as it has been filed in the same shelfmark range as two very closely related and well-known texts. The directly preceding shelfmark BnF Ms Arabe 1704 holds the second and third volumes of Tashrîf al-ayyām wa-l-ușūr bi-sirrat al-Sulțān al-Malik al-Manșūr, a biography of al-Manșūr Qalāwūn written by Muhyȳ l-Dīn b. 'Abd al-Zāhir (d. 692/1293), Shāfic b. 'Alī’s maternal uncle. Furthermore, BnF Ms Arabe 1707 holds find Shāfi' b. 'Alī's own Husn al-manāqib al-sirriyya almuntaza'a min al-sìra l-Zāhiriyya, an abridgment and reworking of his uncle Ibn 'Abd al-Ẓāhir's biography of Baybars. ${ }^{12}$ Three further biographies written

8 Haarmann, Quellenstudien $97^{-101}$ (quotation on 97).

9 White, Content.

10 For a similar argumentation on an 8th/14th century literary offering, see Van Steenbergen, Qalāwūnid.

11 The only exception I am aware of is Hayat Nasser al-Hajji, who used the manuscript as a source but did not identify its author in Internal 205-6. I am grateful to Mustafa Banister for bringing this to my attention. Some episodes of the text are also referred to in Chamberlain, Knowledge.

12 The first has been edited by Murad Kāmil and the second by 'Abd al-'Azīz al-Khuwayțir. 
by these two intimately related authors were known and have been published before. While the manuscript does not carry the author's name due to its first folios having disappeared, it is possible to securely identify the author of BnF Ms Arabe 1705 as the same Shāfi b. 'Alī who wrote Husn al-manāqib on the basis of a number of stylistic mannerisms and, most importantly, a self-attributed epigram concluding a section on the infamous Taqī al-Dīn b. Taymiyya's struggles with the Cairene authorities. A slightly variant version of this poem is unambiguously attributed to Shāfic by Khalī b. Aybak al-Ṣafadī (d. 764/1363) in his biographical dictionary A'yān al-'așr wa-a'wān al-nașr..$^{13}$ Al-Ṣafadì met our author personally and reproduced the poem as one among several for which Shāfi ' b. 'Alī gave an ijāza to al-Ṣafadī. The ijāza itself is dated to $728 / 1328$, so Shāfi' clearly deemed the poem important enough to reproduce it two decades after its initial composition.

That same $i j \bar{a} z a$ is a small gold mine of information about Shāfi's creative activities, as it also contains an extensive list of more than 30 books written by Shāfi` b. 'Alī. In this list, a multivolume biography of al-Nāșir Muhamammad is included under the name Sirat al-Nāșir Muhammad (The biography of al-Nāșir Muhammad) - without a doubt a shorthand for a more elaborate title that now eludes us. A similar work is listed as Nażm al-jawāhir fì sïrat al-Malik al-Nāșir (The string of pearls: The biography of al-Malik al-Nāșir), but it is explicitly referred to as written "in verse" (nazman). Although this title most certainly belonged to another work, I will return to the important concept of nazm, also attested to in Shāfi's writing beyond the domain of poetry as a theoretical concern for understanding this particular work, and indeed the workings of the literary in historiography in general. ${ }^{14}$ The manuscript BnF Ms Arabe 1705 does carry two variants of the title Kitāb ta'rīkh al-saläțin wa-l-asākir (The history of the sultans and armies) on its covering bifolium, but this very unspecific title must be a later addition, perhaps added by a bookseller.

The manuscript consists of 107 folios and is missing both its beginning and ending folios. It commences in medias res during the sultan's second reign, detailing events of the years 703-5/1304-6, but then it jumps ahead to the year 709/1309 with a discussion of the sultan's defection to Karak and abdication of the throne. ${ }^{15}$ Similar to Shāfi's more well-known biography of Qalāwūn, al-Faḍl

13 Al-Ṣafadī, $A^{\prime} y \bar{a} n$ ii, 512. It should be noted that Frédéric Bauden had come to the same conclusion concerning the author's identity independent of my findings.

14 Al-Ṣafadī, Áyān ii, 507. Shāfi b. 'Alī also uses the term when describing his uncle's writing of the sira of Baybars: Husn 56 .

15 There is no noticeable gap in the manuscript, and the title of the new section is even spread across a verso and recto page, so if this is indeed a gap, it must be a copyist's mistake. 
al-ma'thür min sirrat al-sulțān al-Malik al-Manșūr, the text is written predominantly in $s a j$. It contains some compiled material: several poems, two of which are explicitly said to be written by the author, as well as one letter and one official document, both composed by the author. Most of this quoted material does not appear elsewhere, and the historical accounts are also unique to this biography, although parallel (but not derived) versions of most of the events may be found in contemporary and later chronicles and biographical dictionaries. ${ }^{16}$ Like Shāfics other sïras, no later author explicitly reproduced narrative material from this text, and it is quite likely that this manuscript is part of an original presentation copy due to its careful handwriting and wide spacing throughout.

Shāfi' b 'Alī is a fairly well-known author of the period, mostly because of the two sïras he wrote about Qalāwūn, al-Faḍl al-ma'thūr min sìrat al-Malik al-Manșūr, and Baybars, Husn al-manāqib, respectively. The latter is explicitly announced as an abridgment of his uncle Ibn 'Abd al-Z̄āhir's sìra of Baybars (itself published under the title al-Rawd al-zāhir fì sìrat al-Malik al-Ẓāhir), although several researchers have rightly noted that much more than simply summarize his uncle's text, it also critically reworks and adds material. ${ }^{17}$ The author wrote both texts, claiming proximity to the events because of his position as a scribe $(k \bar{a} t i b)$ at court. While a decent number of contemporary and later entries exist for this author in the prosopographical literature of the period, much of what we know about the author's professional activities as kātib comes from the two already known sirras. This is due to his remarkable proclivity to extensively detail his various personal contributions to political and especially diplomatic activities. The author appears to have started his scribal activities sometime around the end of Baybars' sultanate, as he quotes a letter he wrote and sent to that sultan's son, al-Sa'ìd Bereke, informing him about the death of his father. The letter is sent in the name of the Syrian viceroy (nāib al-salțana) Badr al-Dīn Baylik al-Khazindār, so one presumes our author to have been working as a scribe in his service at that point. ${ }^{18} \mathrm{He}$ subsequently rose to prominence under the short but eventful sultanate of alSaīd Bereke, the period of which he describes in quite some detail in al-Fadl

16 In the edition and commentary of the text currently being prepared by Frédéric Bauden and myself, these parallel accounts are identified and their relationship to Shāfi' b. 'Alī's accounts is discussed extensively.

17 Holt, Observations; Northrup, Slave 3 .

18 Shāfi' b. 'Alī, Husn 342-8. The contemporary author 'Izz al-Dīn b. Shaddād also notes that a letter was sent to al-Sa'id Bereke in the name of this viceroy but does not name the scribe who wrote it. Ta'rīkh 224. 
al-ma'thür with increasing personal contributions. Although it is somewhat unclear how he ended up in the sultan's chancery, he claims to have been accorded a prominent position in al-Sa'ìd Bereke's chancery by the powerful dawādār Balabān al-Rūmī (d. 68o/1281). ${ }^{19}$ Shortly before Bereke's deposal, he switched sides to Qalāwūn's camp, under whose reign he would continue to serve, apparently as kātib al-darj (scribe of the bench), until he was famously hit by an arrow in the temple during the Battle of Homs, after which he became at least partially blind. ${ }^{20}$ While he only very ambiguously mentions this event in his own works, a first-person account of the accident is rendered by al-Jazarī in his extensive obituary of Shāfic. Al-Jazarī, al-Ṣafadī, and all other biographers attest that he was sent home after this event (variations of the phrase läzama min-hu bayta-hu are used by various biographers), although some add that he retained his salary. ${ }^{21}$ The sìras of Qalāwūn and Baybars contain a few elements that problematize this proposed run of events, as the author claims to have written several official pieces which should be situated in later periods. While the author's presence in the narrative is noticeably more toned down in the partially preserved sìra of al-Nāșir Muhammad, the text does add two further claims to having written official documents, neither of which are attested elsewhere: a letter addressed to the ruler of Yemen from the year 704/1304 and the caliphal taqlïd composed for al-Nāșir Muhammad's reinstatement as sultan, to which I shall return in more detail below. ${ }^{22}$ It is in any case clear that the author kept on writing prolifically in the half-century after the arrow incident. All the siras contain material that should be dated to well after this event, as should a good deal of our author's poetry quoted in other sources.

19 Shāfic b. 'Alī, Faụl 49.

20 Paulina Lewicka suggests, on the authority of unnamed ophthalmologists, that becoming fully blind due to such an incident would have resulted in the failure of all other brain functions as well; $\check{S} a \bar{f} i^{c}$ 91.

21 The first-person account is in al-Jazarī, Hawādith ii, 429. Other biographical lemmata who mention the author being sent home are: al-Ṣafadī, Ayyān al-așr ii, 503; Nakt 163; alDhahabī, Ta'rīkh iii, 356; Ibn Taghrī-Birdī, al-Manhal vi, 20o; Ibn Ḥajar, al-Durar ii, 184. Divergent but unfortunately not very detailed information is given by Ibn Habīb, who only mentions that "he became blind in old age" (al-darìr 'alā kibar), Tadhkirat 208.

The letter is found on folios $48^{\mathrm{r}}-54^{\mathrm{r}}$, and the taqlìd on folios $96^{\mathrm{v}}-105^{\mathrm{v}}$. 
As noted above, Shāfi wrote another work about al-Nāṣir Muhammad, of which the "thematic phrase" runs as Nazm al-jawāhir, "the string of jewels." ${ }^{23}$ Although that title almost certainly does not apply to the work found in BnF MS Arabe 1705, the meaning implied by this short phrase is helpful in interpreting the cohesion and meaning of the text preserved in the manuscript. Nazm is a particularly potent Arabic term, most often used to refer to poetic composition, but in fact, it bears much wider signification related to a root meaning of organization. Rebecca Gould has pointed to the importance of this "polysemic term" in the Arabic rhetorical tradition, from al-Jāhiz (d. 255/868) to 'Abd al-Qāhir al-Jurjānī (d. 471/1078) and beyond, as denoting "the order that binds together all the elements that comprise a literary text," in the first place the Quran, where the term was used to conceptualize that work's inimitability. ${ }^{24}$ In al-Jurjānī's rhetorical interpretation, which has been likened to Saussurean semiotics, it is the interplay between words (alf $\bar{a} z$, singular lafz), meanings (ma'anni, singular $\left.m a^{i} n \bar{a}\right),{ }^{25}$ and this binding structure, or nazm, that constituted literary language. As such, nazm was essential in forming the cohesion of any linguistic expression. ${ }^{26}$ Taking this understanding of literary composition into account means that the distinction between content and form posited by Haarmann becomes highly problematic, as it distinguishes between aspects that were considered to be fundamentally interrelated. In the following paragraphs, I will show that reading the closing third of the sira, which deals with al-Nāṣir Muhammad's defection, abdication, and ultimate reascension to the throne in the year 709/1309, through this tripartite lens of words, meanings, and binding structure, suggests a fruitful way to conceptualize how authors engaged with history by way of narrative emplotment.

The background of the story discussed in this section involves the complex history of al-Nāșir Muhammad's ascension to the throne. In 693/1293, while still an infant, al-Nāṣir Muhammad had succeeded his assassinated brother alAshraf Khalil as sultan but was deposed soon after, only to be reinstated as sultan from 698/1299 until 709/1309. During this second reign, the still young sul-

\footnotetext{
23 For the term "thematic phrase," see Ambros, Beobachtungen and Hirschler, Medieval 66.

24 Gould, Inimitability 86.

25 This term is exceptionally complex in itself and has been the subject of much research, but I am here referring to it in its most common usage as denoting "meaning." See, for an up-to-date bibliography and thorough etymological discussion, as well as a discussion of laf $z$ near the end of the article, Larsen, Meaning 221 (for lafz). An in-depth discussion of the issue may be found in Key, Language.

Gould, Inimitability 9 o.
} 
tan was dominated by the two powerful amirs, Sallār and Baybars al-Jāshnikīr. While perhaps not as explicit as in other historical sources, this tension is also evident from the first two-thirds of the manuscript Arabe 1705, which details events from this second reign. For example, in an account about the arrival of Īlkhānid envoys in the year 703/1303, it is Baybars who received and honored these envoys before they met with the sultan. ${ }^{27}$ Further on, several accounts deal at length with the hajj undertaken by the viceroy Sallār as well as his later reunion with his brother. ${ }^{28}$ While al-Nāṣir Muhammad is certainly not absent from these first two-thirds of the manuscript - one finds, for example, a laudatory description of a hunting trip and accounts of the birth of an unnamed son, and military endeavors that are carried out in his name - it is clear that he had to share the spotlight with these two powerful men. Things eventually came to a head, and al-Nāṣir Muhammad abdicated, exacerbated from being dominated by these two amirs, after having escaped to Karak under the ruse of wanting to perform the hajj himself. Baybars then ruled for nine months with the regnal title al-Muzaffar until al-Nāșir reconquered the throne and established his authority for the following three decades. The part detailing the transition of the sultan's second to third reign in the manuscript starts at folio $68^{\mathrm{v}}$ and continues until $105^{\mathrm{v}}$. It provides not only a quite extensive account of the events but also a taqlìd (diploma of investiture) written by Shāfic himself in the name of the caliph al-Mustakfì bi-llāh (d. 740/1340) for al-Nāșir Muhammad's reinstatement as sultan. Shortly after the quotation of this document, the manuscript is cut off after folio 107 .

As it is impossible to study the complete text due to its fragmentary survival, we will focus on this particular section. This will allow us to study various aspects of the text's narrative construction within a continuous and thematic whole. This continuity and cohesiveness may result partly from this section having been a stand-alone text before being integrated into the sira. We know Shāfi similarly integrated an earlier written text on the Battle of Homs in 68o/1281 in al-Fadl al-ma'thür, although there he clearly signposted having done so and named the text separately in the $\ddot{j} \bar{a} z a$ reproduced by al-Ṣafadī. ${ }^{29} \mathrm{I}$ see at least five arguments in favor of the text's initial composition as a standalone treatise. First is the fact that the intervening four years between this part and the directly preceding accounts are discussed only in very broad terms (and

\footnotetext{
27 BnF ms Arabe $1705,11^{\mathrm{r}}-2^{\mathrm{r}}$.

28 BnF Ms Arabe $1705,19^{\mathrm{r}}-2 \mathrm{O}^{\mathrm{v}}, 45^{\mathrm{r}}-6^{\mathrm{r}}$.

29 Shāfic b. 'Alī, al-Faḍl, $79-85$ (statements as to the text's previous stand-alone character are made at the beginning and end of this section); al-Ṣafadī, A'yān ii, ${ }^{\circ}{ }^{\circ}$, noted as al-Masā' l-murdiyya fi l-ghazwa l-Himșiyya, or "The satisfactory efforts in the Battle of Homs."
} 
only further on in the section) insofar as they were deemed relevant to this section's narrative. Second is $s a j$, which is more consistently sustained here than elsewhere in the sira. Third, in the first part of the sira, Shāfic concludes the majority of accounts with a variation of the somewhat idiosyncratic statement that an event happened "in this way" ('alā hädhihi l-șüra), which he completely abandons in this later part. ${ }^{30}$ Fourth, the introductory lines of this section bear a resemblance to the traditional tahmid section at the start of any Islamic text. Lastly, and most importantly for our purposes, its narrative construction of a departure for Syria and an eventual glorious return to Cairo makes for a cohesive narrative whole. However, even if the text was separately composed, it was clearly reworked to be integrated into the sïra. This is evident from Shāfics cross-references to things he has mentioned earlier and the suggestion that the following narrative should be read as a reaction to those events.

\subsection{Analysis 1: Introduction}

The tahmid-like qualities of the beginning of the section are evident from the first lines:

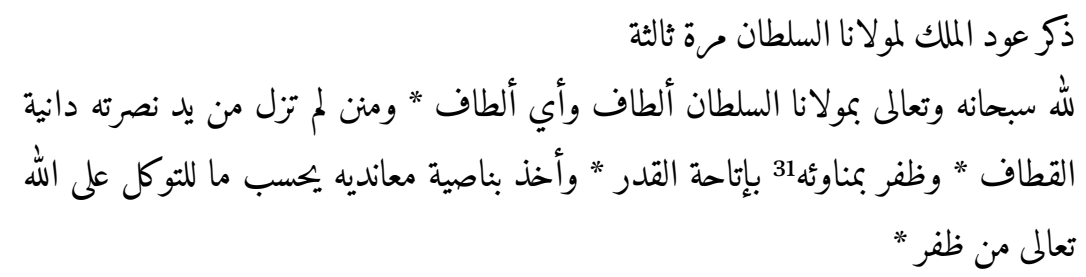

An account of the return of kingship to our lord the sultan for a third time.

God be praised, most high. For our lord the sultan there are benevolences-and what benevolences these are! — and graces, which continue to bestow on him the harvest through the hand of His support. And so too the victory in his struggle through the foreordainment of destiny, taking hold of the forelock of his enemies in reckoning the victory that belongs to [those who] trust in God most high. ${ }^{32}$

$30 \quad$ BnF ms Arabe $17059^{\mathrm{r}}, 13^{\mathrm{r}}, 15^{\mathrm{r}}, 18^{\mathrm{r}}, 22^{\mathrm{v}}, 23^{\mathrm{v}}, 35^{\mathrm{r}}, 46^{\mathrm{r}}, 49^{\mathrm{r}}, 57^{\mathrm{r}}, 65^{\mathrm{v}}, 67^{\mathrm{r}}$. While not an unusual phrase per se (Ibn 'Abd al-Ẓāhir also uses it three times in Tashrîf 29, 88), it does seem to have been a mannerism of Shāfi' to use it so extensively. He also uses variations of it several times in al-Fadl 28, 38, 59, 69, 100, 114, 118, 139, 140, 150, 156, 162; and Husn 66, 113, $118,172,264,321$.

31 Variant spelling of munāwa'a.

32 BnF ms Arabe $170569^{\mathrm{r}}$. I am grateful to Mohamad Meqdad for his advice on this translation. 
This highly laudatory and rhetorically dense introductory discourse, replete with the ambiguous qualities of the Arabic lexicon, continues for several more lines. As is typical in introductory discourses, at the end the topic is discussed in more detail, albeit without a formal ammā ba'd to signpost this transition:

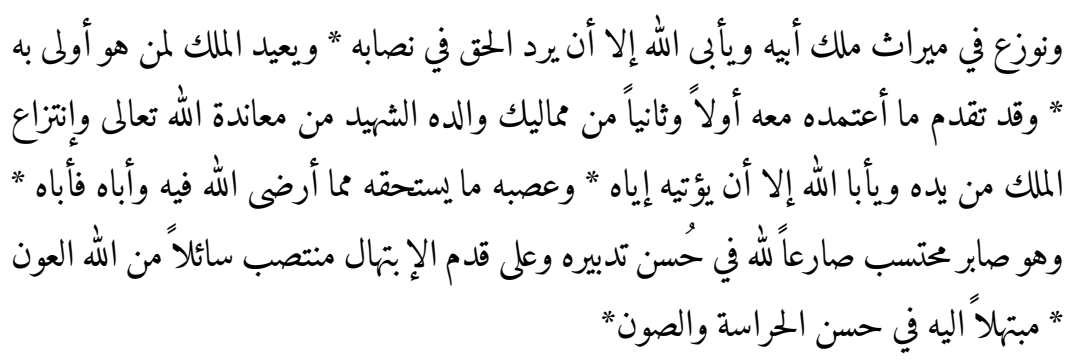

The inheritance of his father's kingship was contested [but] God willed rightfulness to return to its origin, and he caused the kingship to return to who is most deserving of it. It has been mentioned before how the mamlūks of his father the martyr [Qalāwūn] employed him a first and second time in resistance to God the most high and [how] they removed kingship from the hand [of our lord the sultan], even though God wanted nothing but give [the kingship] to [our lord the sultan]. And [so the sultan] applied himself with zeal to what he was entitled to, which it pleased God [to accord] to him and his father, but he was rejected. But he is patient in anticipation of God's reward, struggling for God in the excellence of his management, upright in beseeching, asking God for help, and praying to Him for the blessing of sustained protection. ${ }^{33}$

This introductory discourse announces the fundamental features of the text to follow: the sultan as chosen by God and favored by fate, the accusatory tone against Qalāwūn's former mamlūks who dominated al-Nāșir's first two reigns, and the departure-return structure that is evident from the title and the suggestion that al-Nāṣir overcame his difficulties and established his Godly ordained authority. These narrative stakes are in the following pages emplotted into a cohesive historical account that may be identified with a very widely used narrative form of departure and return. 


\subsection{Analysis 2: Departure and Return}

The departure-return structure evident in this section has many precedents in world literature, and it is even one of the integral ways in which stories work according to structuralist theorists such as Vladimir Propp, Northrop Frye, and those who worked on Jungian archetypes, such as Joseph Campbell. ${ }^{34}$ The basic format involves a hero having to relinquish a comfortable, static situation to overcome a number of difficulties before ultimately returning to his rightful position. While much of the research on these structures has focused on stories that should be situated within Western mythical and folklore settings, these are not at all alien to the Islamic textual tradition. They are a major building block of the Prophetic sira, in which the point at which Muhammad leaves Mecca for Medina is even the historical crux around which time itself would come to be measured and his triumphant return to Mecca heralded as the start of Islam as a world-conquering religion. The narrative structure is also present in other works from the very same corpus of early Mamluk sīras. Both Shäfi's sìra of Qalāwūn as well as Ibn 'Abd al-Zāhir's important sìra of Baybars contain variants of this structure. ${ }^{35}$ I will be understanding this type of structure not through the structuralist lens of Propp, Frye, or Campbell, but with Paul Ricoeur, who argued that such paradigmatic structures should be seen as part of "the grammar that rules the composition of new works." In this view, any act of writing is a constant interplay between such received structures and the innovative authorial practice, which results in new configurations of these two poles of the creative process, which he calls "sedimentation" and "innovation." 36 Beyond identifying the fact that an author made use of such structures, it is of critical importance to understand, on the one hand, the specific ways in which they are integrated into a particular text and, on the other hand, what meaning they may be said to convey.

One of the clearest ways in which Shāfi's creative development of this structure becomes clear is through his application of symmetrical relations. Consider, for example, the extensive descriptions of the ceremonial of al-Nāșir Muhammad's departure and return, which more or less bookend the momentous events. Our author uses these to stress the growth of the sultan's glory. While his departure is framed in laudatory language but with several comments denoting the impure intentions of his entourage, when he returns, any trace of doubt is erased, and the sultan ascends the throne in excellent fashion. While his departure from the citadel is described as "he descended from his Citadel

34 Propp, Morphology; Frye, Anatomy; Campbell, Hero.

35 I discuss this more extensively in the fifth chapter of my $\mathrm{PhD}$ dissertation.

36 Ricoeur, Temps i, 134 . 
accompanied by his enemies though they made believe that they were his helpers," al-Nāșir wisely escapes from this tension to squash it upon his return. ${ }^{37}$ Contrastingly, the event of his return to the citadel is described as follows:

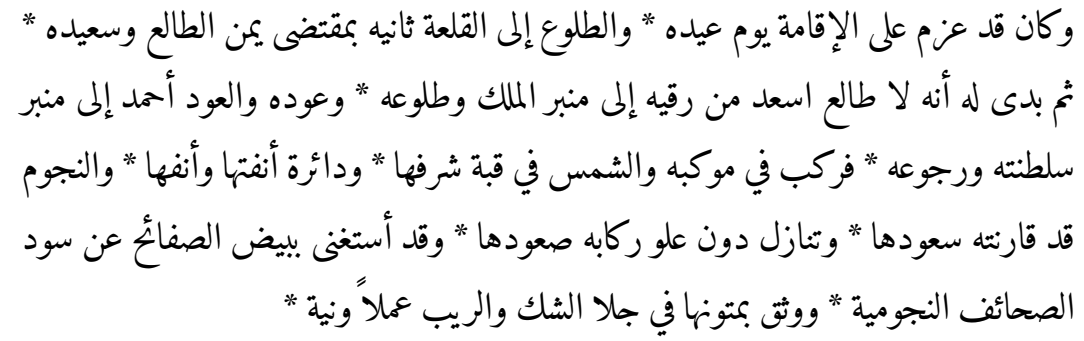

He had decided to celebrate the day of his Feast [of Breaking at the Pond of the Well, see excerpt quoted below] and to ascend the Citadel on the second day [of the Feast] in accordance with the good fortune and radiance of the ascendant star of destiny. Then it appeared to him that there was no ascendant star more radiant than his rise to the pulpit of kingship, his ascension of [the throne], and his return - for finishing what one started is commendable - to the pulpit of his sultanate and his restitution. So he rode triumphantly as the sun in the dome of its elevated place and [in] the sphere of its pride and freshness. And the stars had aligned him to their good fortune, so that he dismounted [to attain on foot] without the greatness of his mounts the insurmountable difficulty, not needing the whitest of camels to [reach] the power of the astronomical pages, trusting in [those pages'] contents [in his struggle] against the doubt manifest and the suspicion, in action and intention. ${ }^{38}$

This is Shāfic at his most dense, displaying his command of the vast lexical and proverbial wealth of the Arabic language, playing with richly layered and ambiguous terms. These lines may be seen as lying firmly within the panegyrical tradition in which astronomical metaphors abound as well, but they also refract in dazzling prose the major narrative point being made in this section: the sultan's return to power as proof of his guidance by fate. This was an action of excelling, attainment of a predestined position by way of overcoming the doubts and uncertainties and, indeed, the injustice of the sultan's previous reigns. 


\subsection{Analysis 3: Narrating Ideal Rule through Symmetry and Growth}

While the actions described above are both directly related to the sultan, Shāfi's symmetry is not always linear and plays with motifs that are spread across the section and attributed to various narrative agents. The Pond of the Well, from which the above-quoted action of the sultan's return emanates is, for example, a site of major importance in the section where much symbolic symmetry is situated. In an earlier part, our author describes the actions of alNāṣir Muhammad's very young son at this very same place. The young boy had set out to join his father in Karak, accompanied by the sultan's harem.

$$
\begin{aligned}
& \text { وحين خرج الركب من الديار المصرية خرج ولده المشار اليه وصحبته الأدر المصونة وخيموا }
\end{aligned}
$$

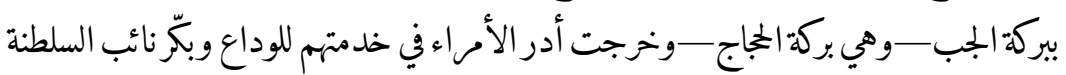

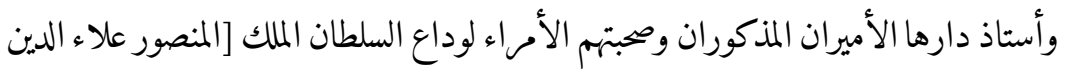

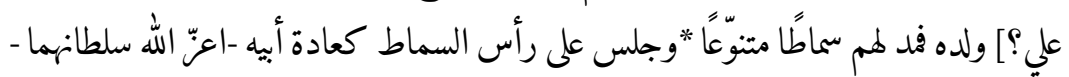

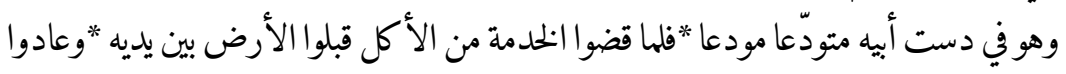

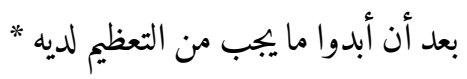

When the caravan left the Egyptian lands the aforementioned son [alManșūr 'Alī] also left accompanied by the Harem women camping next to the Pond of the Well — that is, The Pond of the Pilgrims - and the women of the amirs in their service left to make their farewells. ${ }^{39}$ The sultanate's viceroy and ustādār, the two aforementioned amirs [Sallār and Baybars al-Jāshnikīr] and their accompanying amirs woke up early to say farewell to the sultan al-Malik [al-Manșūr] his son, and he laid down for them a varied meal. He sat at the head of the banquet according to the habit of his father-may God strengthen the power of both of themas he was left in the place of honor of his father as the person who sees off [those left behind]. And when they finished the session as far as the food was concerned [the amirs] kissed the ground in front of him, and they returned after they had expressed the necessary salutations toward him. ${ }^{40}$

Reading $\bar{a} d u r$ instead of $a d u r$. The first is a plural form of $d \bar{a} r$, which was often used to denote noble wives. Another option would be to read adurr as an unattested plural form of durra. For both forms (though with durra only in the singular) cf. 'Abd ar-Rāziq, La femme 99-101.

BnF Ms Arabe $170575^{r-v}$. 
The passage is interesting on several levels. In the manuscript, the name of the son whose actions are described here is consistently erased. This may have been the case because al-Manșūr 'Alī, who is the most likely candidate to have performed this role, died shortly after the return of the sultan from Karak. ${ }^{41}$ This would either suggest that this part was written before 709/1310, but the manuscript as a whole only finished later, or that a later reader erased these names from the manuscript for an unknown reason. One presumes that the name was erased so as not to provoke the sultan's grief. ${ }^{42}$ On a narrative level, the account is interesting because of the ways in which it plays with the performance of power and the relationships between those who held power. The fact that the two most highly placed amirs in the sultanate, those who effectively directed the affairs of the sultanate, are here portrayed as humbling themselves before the sultan's infant child creates a complex questioning of the nature and rituals of power. That the very young son of al-Nāșir Muhammad is said to have behaved "according to the habit of his father" (ka-'ädat abi-hi) not only shows him to be a worthy heir of the sultanate but also highlights the contextual logic of that power. Perhaps, most importantly, the scene is mirrored and extended at the end of the section when al-Nāșir Muhammad returns to Cairo, just before the earlier quoted laudatory excerpt on the sultan's celestial good fortune:

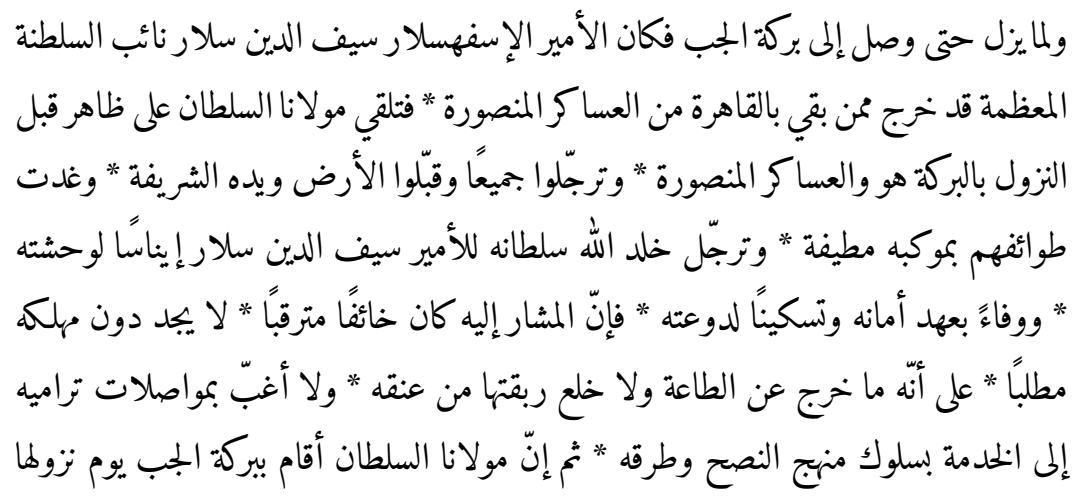

41 Al-Malik al-Manșur 'Alī (d. 710/1310) was only five or six years old at the time. Bauden, Qalawunid.

42 The son is mentioned three times on folios $75^{\mathrm{r}}, 75^{\mathrm{v}}$, and $76^{\mathrm{r}}$, all erased. The much-later historian Ibn Ḥajar al-'Asqalānī notes that this son came to al-Nāṣir Muhammad from Karak when the latter had returned to Cairo (which would mean that the son did indeed join his father before the sultan's reascension) and was loved by his father because he was his only child at that point. He is said to have died while his father was hunting. Al-Durar iii, 115 (nr. 262). 


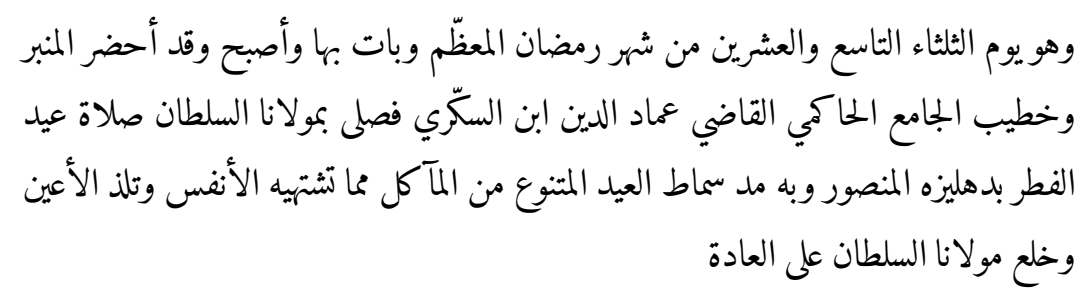

[The sultan] did not stop [going from resting place to resting place] until he reached the Pond of the Well. And the army commander Sayf al-Din Sallār, viceroy of the glorified sultanate, had come out from among those who had stayed in Cairo of the victorious armies, and he and [these] victorious armies met our lord the sultan outside before they alighted at the Pond. They all dismounted, and they kissed the ground and [the sultan's] noble hand, and their groups became encircled by [the sultan's] convoy. [Then the sultan] dismounted for the amir Sayf al-Dīn Sallār in friendliness to his cheerlessness, fulfilling the agreement of his security and pacifying his anxiety. For the aforementioned [Sallār] was frightened and fearful, searching for a way out of his [imminent] destruction, entreating that he had not left obedience [to the sultan], and had not taken off its noose from his neck. He did not tarry with the communications that came to his service by way of the procedure and methods of good advice. After that, our lord the sultan stayed in the Pond of the Well for the day of his alighting. This was Tuesday the 29th of the glorified month Ramadān and he stayed the night there, and the pulpit and the preacher of the Hākim mosque, the $q \bar{a} d^{\prime} \bar{\imath}$ Imād al-Dīn b. al-Sukkarī, were brought. He prayed with our lord the sultan the prayer of the Feast of Breaking in his victorious dihliz tent, where the Feast banquet was laid out with all the varieties of food souls may desire and by which eyes may be pleased. And our lord the sultan distributed khil'as in the usual way. ${ }^{43}$

Such descriptions of ceremonial are not exceptional, and that similar things would happen at these moments is also self-evident in the context of a strongly codified courtly habitus, but the positioning of these excerpts more or less at either end of the section highlights Shāfi's symmetrical construction, as well as his play with motifs of the ideal rule to construct an engaging narrative. In the first excerpt he does so by transplanting these practices to the young boy 'Alā' al-Dīn, who admirably performs his father's duties, but in the second excerpt, the sultan himself, now a fully grown man, is presented as a paragon of 
the ideal rule. There is an element of physical growth that is creatively played with here: Shāfic suggests that it is the sultan's coming of age that allows him to finally triumph over his oppressors and come into his own as the ideal ruler. Furthermore, in this scene, the return to obedience-a veritable topos of the period's historiography - is interwoven with the sultan's own performance of his magnanimity. The enemies who made him believe that they were allies are finally either chased off or brought under the sultan's newly asserted authority.

The symmetry of the "story" is as such unequal and spread out across the sections in various ways. Recurring motifs, places, and discourses are used as a means to stress growth and excellence. Sometimes the symmetry also works as a contrast: The most obvious example of this is the respective portrayal of alNāșir Muhammad (and by extension the son in the account above) and Baybars al-Jāshnikīr, who reigned as sultan for nine months while al-Nāṣir Muhammad was in Syria. While the first is portrayed as having fortune and fate by his sidefor example, by way of the celestial metaphors noted above or in an anecdote involving a miraculous escape from a crumbling bridge- the latter is from the start portrayed as an incompetent ruler who only sits on the throne by the grace of his supporters. ${ }^{44}$ Once those supporters start switching sides to al-Nāșir Muhammad's camp, Baybars' authority crumbles. This is again symbolically refracted: When the news of al-Nāșir Muhammad's move toward Cairo with growing military support reaches Baybars, he is said to have thrown his turban on the ground in anger. ${ }^{45}$ Considering the widely attested importance attached to headgear by sultans in this period, this can be read as a highly symbolic relinquishment of authority. ${ }^{46}$

The contrasting symmetry is also structurally clear. Consider, for example, the titles of these four consecutive section titles:

44 The anecdote about the crumbling bridge may be found at BnF Ms Arabe $170574^{\text {r-v }}$. Other versions of this anecdote are related by, among others, al-Mufaḍal, Histoire iii, 141; Ibn Kathīr, al-Bidāya xviii, 79; Ibn Taghrī Birdī, al-Manhal x, 272-3.

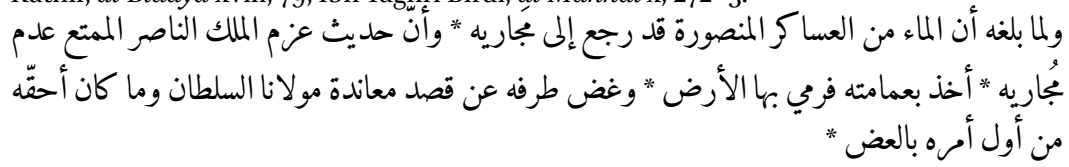

BnF MS Arabe $170586^{v}$. Note also that Baybars is only rarely referred to by his regnal title and more often by a reference such as "the aforementioned" (al-mushār ilay-hi) or by his personal name Baybars, whereas al-Nāșir Muhammad is either called by his regnal title or by the reverential mawlā-nā al-sulțān (our lord the sultan). Furthermore, the whole section includes a lot of word play on the roots $n-s-r$ and $z-f-r$, which both denote victory. 


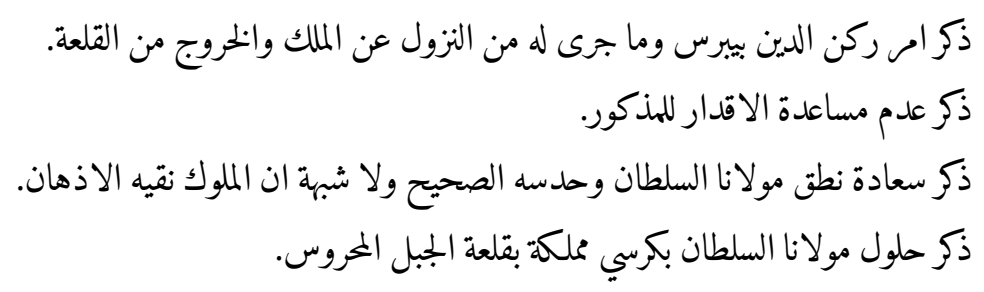

The case of Rukn al-Dīn Baybars and what befell him in descending from kingship and leaving the citadel.

The lack of support of fate for the aforementioned [Rukn al-Dīn Baybars].

The bliss of the utterance of our lord the sultan and his correct surmise - and there is no doubt that kings are pure minded!

The ascension of our lord the sultan to the throne of his kingdom in the Citadel. ${ }^{47}$

In these titles, and even more so in the content they signpost, Baybars is portrayed as having destiny against him, in large part due to his own actions, which are, among other things, described with the important signifier "corruption" ( fas $\bar{a} d),{ }^{48}$ while al-Nāșir Muhammad is basically flying on the wings of fortune. The third of these sections, which contains a speech in saj' by the sultan, is even concluded by the statement that "there is no doubt that Egypt['s future] is auspicious and this good omen is a confirmation [of that]."49

The return of the sultan to his throne is as such shown to have been a triumph of fate, but the narrative also suggests that this attaining of the rightful position was not just a given. To achieve his goal, the sultan needed to take action and overcome his limitations. The section can be read as a moral exemplum, a literary meditation on the nature of power. The good and bad choices of power-wielding and their consequences are, as it were, sprinkled across the dense prose in a contrastive and engrossing narrative that leads the reader into a literary universe that is not only rich in rhetoric but also in meaning.

47 BnF ms Arabe $170586^{\mathrm{r}}-90^{\mathrm{r}}$.

48 Ibid. $89^{\mathrm{r}}$.

49 BnF MS Arabe 1705 90r. ولا شك في أن مصر بفالاتها ومصداقه هذا الفال. 


\subsection{Analysis 4: The Caliphal Taqlid}

Conspicuously absent from this narrative, and indeed from much of the sira in general, is Shāfi' b. 'Alī himself as the kātib whose presence was so dominant in his other texts. Although it is not spelled out, it is likely that our author, at this point, did not enjoy the same position toward the sultan as he did a few decades earlier. Of course, he is always present by way of his intricate prose, but he also makes his presence as a narrative agent felt at one crucial point at the end of this section, as the author of the caliphal taqlid reasserting the sultan's dominance. This document is introduced as follows:

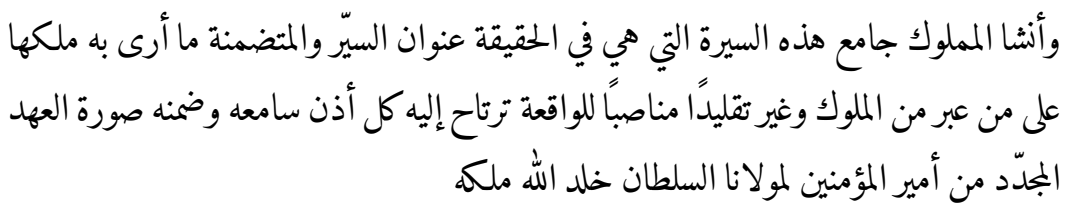

The mamlūk who compiled this sira-which, in truth, is the epitome of siras, and it details its king's deeds which exceed those of kings whose days have elapsed-composed the diploma of investiture to be declared for the occasion, which satisfied every ear that heard it, and its contents take the form of the renewed contract from the Commander of the Faithful for our Lord the Sultan-may God perpetuate his kingship. ${ }^{50}$

The statement is, of course, significant as a claim to historiographical authority and an insight into the author's general evaluation of his biographical project, but it is also contextually significant because of its relation to the preceding part and the text of the taqlid itself. However, we need to read beyond the pages of the sira itself to evaluate the full weight of this statement. Al-Ṣafadī tells us that when Baybars al-Jāshnikīr ascended the throne, he too had a taqlìd written for his ceremonial investiture and that this taqlìd was written by Shāfi's relative 'Alā' al-Dīn b. 'Abd al-Zāhir (d. 717/1317), a leading kātib himself and grandson of the famous Muhyī l-Dīn b. 'Abd al-Zāhir. ${ }^{51}$ The present taqlìd even seems to refer to 'Alä' al-Dīn's text by stating that "this contract ('ahd) that invalidates

50 BnF Ms Arabe $170596^{\mathrm{r}}$.

51 In fact, two taqlid documents were composed for Baybars II, the second apparently as a last-minute attempt to assert his authority against al-Nāṣir Muhammad's rising support for a return to power. For a discussion of the contents of these contracts (though not of their authors), see Banister, Abbasid 397-8. On the first contract, see also Nielsen, Secular 88 . 
any contracts like it drawn up for whom is like [the sultan]."52 This statement positions the diploma as a reaction against a former contract, which we can contextually surmise to have been 'Alä' al-Dīn's diploma for Baybars II. While 'Alā' al-Dīn was extremely influential at several points during the late 7 th/13th century, his relationship to al-Nāṣir Muhammad seems to have been a troubled one, and the sultan is even said to have hated him, among other things, because he composed the taqlīd for Baybars II. ${ }^{53}$ Shäfi' never actually mentions 'Alä' alDīn, although he does mention 'Alā' al-Dīn's father (and his own cousin) Fath al-Dīn b. 'Abd al-Z̄āhir repeatedly in al-Faụll al-ma'thūr and Husn al-manāqib. These mentions have made P.M. Holt conclude that "for his uncle and cousin [Shāfi'] had clearly little affection, even if he showed them formal respect."54 Although other evidence suggests that the relationship between him and his relatives was probably more complex, there does seem to have been a significant degree of competition between the various members of the Banū 'Abd al-Zāhir. That 'Alā' al-Dīn held positions at times when Shāfi' himself likely did not due to his blindness, and that the former's position may have been in real danger considering the well-known purging of the court's elites at the start of al-Nāșir Muhammad's third reign, may explain why Shāfi' here reproduces a taqlïd written by himself. ${ }^{55}$ Indeed, it is even possible to read this taqlïd as a showpiece in which the author presented himself as a worthy successor to this informal position of leading kâtib of the realm.

The question of whether this taqlìd written by Shāfic was also effectively used in the sultan's ceremonial third investiture or was only a textual exercise, in line with a number of other documents quoted by the author in al-Fadl al-ma'thür, is not relevant within the context of the sira.${ }^{56}$ Here, the taqlid serves to perform Shāfi"s claim of being a masterful kātib, as part of what may be called a sort of creatively constructed resumé: a performative document that was meant to convey to its reader the wide-ranging writing abilities of its author. While the manuscript of the sira is very likely a presentation copy, we do not know to whom it was offered. However, considering the time frame and the highly demanding register in which the text was written, one is tempted to imagine it being offered to an important agent at the court of al-Nāșir Muhammad-perhaps even the sultan himself-at a time when elite circles were being purged and replaced by close confidants of the sultan. As such,

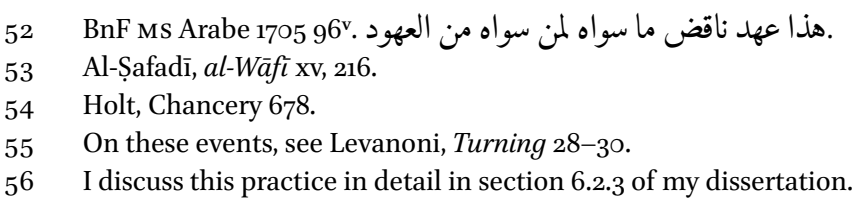


Shāfi' may have intended his text to facilitate either the receiving of a new position or the strengthening of his relationship with leading elites. To do so, he simply displayed that type of labor for which he could be relied on: the composition of excellent prose celebrating the sultan's achievements.

Literary, historical, and even documentary elements cannot be separated in this section, and indeed in this sirra in general. They are all fundamentally interwoven and communicate across their respective discursive boundaries. It is exactly the literary approach to these events which drives Shāfi's historical emplotment of both the narrative in the sira and the taqlïd. Of course, such an approach is not unprecedented in Islamic historiography, but the specific format it takes may be said to amount to a slightly different type of literarization, which is more related to von Grunebaum's definition of the term than Haarmann's: a fundamental entanglement of style and content. Instead of von Grunebaum's negative evaluation of this tendency, however, we can see how such a literary approach could, in fact, be a very powerful narrative tool by which authors not only presented important historiographical interpretations of the past but also performed their own authorial agency. All the evidence suggests that Shāfi' b. 'Alī was not actually active anymore in the chancery in this period, so we may see this text, as well as the two other siras he wrote, as performances of his authorial abilities and a way of showcasing the continued excellence of his prose despite his failing eyesight. Perhaps it even suggests how worthy it would be to reinstate the author at court, or at least how important it would be to maintain close relations with him. Patronage in this context is not simply about legitimization anymore, but it is about a complex negotiation of social status by way of performative displays of linguistic dexterity because it was this superior command of language and meaning that was required of leading kuttāb.

Although it was written by a contemporary author, this particular account of al-Nāșir Muhammad's abdication and reascension may not tell us much that is new about the motives of the political agents involved and maybe not even much about what wide segments of society in the period thought about these doubtlessly tumultuous events, but it is highly informative of the ways in which historians emplotted meaningful versions of the past. 


\section{Bibliography}

\section{Manuscripts}

Shāfi' b. 'Alī, Sīrat al-Malik al-Nāṣir, Paris, Bibliothèque nationale de France, Ms Arabe 1705 .

\section{Primary Sources}

al-Dhahabī, Ta'rīkh al-Islām wa-wafāyāt al-mashāhir wa-l-ąām, 53 vols., ed. 'U. Tadmurī, Beirut 1990.

Ibn 'Abd al-Ẓāhir, Tashrīf al-ayyām wa-l-'uṣūr bi-sīrat al-Malik al-Manșūr, ed. M. Kāmil, Cairo 1961.

Ibn Habīb, Tadkhirat al-nabīh fì ayyām al-Manșūr wa-bānī-hi, 2 vols., ed. M.M. Amīn, Cairo, 1976-86.

Ibn Hajar, al-Durar al-kāmina fì àyān al-mīa al-thāmina, 5 vols., ed. S. al-Karnakawī, Beirut 1993.

Ibn Kathīr, al-Bidāya wa-l-nihāya, 18 vols., ed. 'A.b. 'Alī al-Muḥsin al-Turkī, Cairo 1998. Ibn Shaddād, Ta’rīkh al-Malik al-Zāhir, ed. A. Huțayț, Wiesbaden 1983.

Ibn Taghrī Birdī, al-Manhal al-șāfı wa-l-mustawfi ba'da l-wāfì, 13 vols., ed. M.M. Amīn, Cairo 1990.

al-Jazarī, Hawādith al-zamān fĩ anbā̄i-hi wa-wafayāt al-akābir wa-l-a'yān min abnā̉i-hi, 2 vols., ed. 'U.'A. Tadmurī, Sidon Beirut, n.d.

al-Mufaḍạal b. Abi l-Faḍāil, Histoire des sultans mamelouks, 3 vols., ed. and transl.

E. Blochet, Turnhout 1982.

al-Ṣafadī, Nakt al-himyān fìnukat al-'umyān, ed. A. Zakī Bak, Cairo 1911.

al-Ṣafadī, A'yān al-aṣr wa á wān al-nașr, 6 vols., eds. Abū Zayd et al., Beirut and Damascus 1998.

al-Ṣafadī, Kitāa al-Wāfí bi-l-wafāyāt, 29 vols., eds. A. al-Arnāwūṭ and T. Mușțafā, Beirut 2000.

Shāfi b. 'Alī, Husn al-manāqib al-sirriyya al-muntaza'a min al-sīra l-Ẓāhiriyya, ed. 'A. alKhuwayțir, Riyadh 1976, repr. Riyadh 1989.

Shāfi' b. 'Alī, al-Fậl al-ma'thūr min sīrat al-Malik al-Manșūr, ed. 'U. Tadmurī, Sidon Beirut 1998.

\section{Secondary Sources}

'Abd al-Rāziq, A., La femme au temps des mamlouks en Egypte, PhD diss., Université Paris I Sorbonne 1972.

Ambros, A.A., Beobachtungen zu Aufbau und Funktion des gereimten klassisch-arabischen Buchtitels, in WZKM 80 (1990), 13-57.

Banister, M., The Abbasid caliphate of Cairo (1261-1517): History and tradition in the Mamluk court, PhD diss., University of Toronto 2015. 
Bauden, F., The Qalāwunids: A pedigree, in: http://mamluk.uchicago.edu/qalawunids/ qalawunid-pedigree.pdf, last accessed October 26, 2018.

Campbell, J., The hero with a thousand faces, Princeton 1968.

Chamberlain, M., Knowledge and Social Practice in Medieval Damascus, 119o-1350, Cambridge 1994 .

Conermann, S., Tankiz ibn 'Abd Allāh al-Ḥusāmī al-Nāṣirī (d. 740/1340) as seen by his contemporary al-Ṣafadī (d. 764/1363), in MSR 12/1 (2008), 1-24.

Frye, N., Anatomy of criticism: Four essays, Princeton 1957.

Fuess, A., Sultans with horns: The political significance of headgear in the Mamluk empire, in $M S R$ 12/2 (2008), 71-94.

Gould, R., Inimitability versus translatability, in The translator 19/1 (2013), 81-104.

Guo, L, Early Mamluk Syrian historiography: Al-Yūnīnìs Dhayl Mir'at al-zamān, i, (IHC 21), Leiden 1998.

Haarmann, U., Auflösung und Bewahrung der klassischen Formen arabischer Geschichtsschreibung in der Zeit der Mamluken, in ZDMG 121/1 (1971), 46-6o.

al-Hajji, H.N., The internal affairs in Egypt during the reign of sultan al-Nāṣir Muhammad b. Qalāwūn (709-741/1309-1341), Kuwait 1978.

Hirschler, K., Medieval Arabic historiography: Authors as actors, London 2006.

Holt, P.M., An early source on Shaykh Khaḍir al-Mihrānī, in BSOAS 46/1 (1983), 33-9.

Holt, P.M., Some observations on Shāfi ' b. 'Alī's biography of Baybars, in Jss 29 (1984), $123-30$

Holt, P.M., A chancery clerk in medieval Egypt, in The English historical review 101/400 (1986), 671-9.

Key, A. Language between God and the poets: Ma'nā in the eleventh century, Oakland 2018.

Langner, B., Untersuchungen zur historischen Volkskunde Ägyptens nach mamlukischen Quellen, Berlin 1983.

Larsen, D., Meaning and captivity in classical Arabic philology, Journal of Abbasid studies 5 (2018) 177-228.

Levanoni, A., A turning point in Mamluk history: The third reign of al-Nāsir Muhammad Ibn Qalāwūn, 1310-1341, Leiden 1995.

Lewicka, P., Šăf' Ibn 'Alı̀'s biography of the Mamluk Sultan Qalāwūn, Warsaw 2000.

Malti-Douglas, F., Dreams, the blind, and the semiotics of the biographical notice, in $S I$ 51 (1980) 137-62.

Mazor, A., The topos of predicting the future in early Mamluk historiography, in S. Conermann (ed.), Mamluk historiography revisited: Narratological perspectives, Bonn 2018, 103-19.

Nielsen, J.S., Secular justice in an Islamic state: Mazālim under the Bahrī Mamlūks, 662/1264-789/1387, Leuven 1985.

Northrup, L.S., From slave to sultan: The career of al-Manșür Qalāwün and the consol- 
idation of Mamluk rule in Egypt and Syria (678-679A.H./1279-129oA.D.), Stuttgart 1998.

Noth, A., Quellenkritische Studien zu Themen, Formen und Tendenzen frühislamischer Geschichtsüberlieferung, Bonn 1973.

Noth, A., and L. Conrad, The early Arabic historical tradition: A source-critical study, London 1994.

Propp, V., Morphology of the folktale, transl. L. Scott, Austin 1968.

Radtke, B., Einleitung, in Kanz al-durar wa-jāmic al-ghurar, Erster Teil: Kosmographie, Cairo Wiesbaden 1982.

Radtke, B., Zur "Literarisierten Volkschronik" der Mamlukenzeit, in Saeculum 41/1 (1990), 44-52.

Radtke, B., Weltgeschichte und Weltbeschreibung im mittelalterlichen Islam, Beirut Stuttgart 1992.

Radtke, B., Die Literarisierung der mamlukischen Historiografie: Versuch einer Selbstkritik, in A. Vrolijk and J.P. Hogendijk (eds.), O ye gentlemen: Arabic studies on science and literary culture. In honour of Remke Kruk, Leiden 2007, 263-74.

Ricoeur, P., Temps et récit, 3 vols., Paris, 1983-5.

Robinson, C.F., Islamic historiography, Cambridge 2003.

Van Steenbergen, J., Qalāwūnid discourse, elite communication and the Mamluk cultural matrix: Interpreting a 14th-century panegyric, in JAL 43 (2012), 1-28.

von Grunebaum, G., Medieval Islam: A study in cultural orientation, Chicago and London 1953 .

Weintritt, O., Formen spätmittelalterlicher Islamischer Geschichtsdarstellung: Untersuchungen zu an-Nuwairī al-Iskandarānīs Kitāb al-ilmām und verwandten zeitgenössischen Texten (втS 45), Beirut Stuttgart 1992.

White, H., The content of the form: Narrative discourse and historical representation, Baltimore 1987 . 